\begin{tabular}{lll}
\hline & JSM (10) (1) \\
\hline
\end{tabular}

\title{
MUSIC ACCOMPANIMENT OF JAPIN CARITA SOUTH KALIMANTAN
}

\author{
Noor Cahaya \\ Department of Indonesian Language and Literature Education, Universitas Lambung \\ Mangkurat, Indonesia \\ Benny Mahendra \\ Department of Drama, Dance, and Music Education, Universitas Lambung Mangkurat, \\ Indonesia \\ Muhammad Najamudin \\ Department of Drama, Dance, and Music Education, Universitas Lambung Mangkurat, \\ Indonesia
}

\begin{tabular}{|c|c|}
\hline Article Info & Abstract \\
\hline $\begin{array}{l} \\
\text { Keywords: } \\
\text { Music accompaniment, } \\
\text { Japin } \\
\text { Carita, Theater }\end{array}$ & $\begin{array}{l}\text { This research was conducted due to the lack of public knowledge about the music } \\
\text { accompaniment of Japin Carita from South Kalimantan. This research focused more on the theory } \\
\text { and practice of music science regarding the music accompaniment of this local South Kalimantan } \\
\text { theater. This research used naturalistic qualitative method because it was held in natural conditions } \\
\text { (natural setting), this method is also called the ethnographic method. Data gathering techniques } \\
\text { include; observation, interview, documentation. Data analysis techniques include data reduction, } \\
\text { data presentation, and verification. Japin Carita is a traditional theater art from South Kalimantan } \\
\text { which is derived from the art of Japin, a dance that originates from Arab. The word Japin in } \\
\text { Arabic originating from the word zafn which means fast footwork, and just like the definition } \\
\text { Japin dance movement is indeed prioritizing foot movements. The structure of musical forms that } \\
\text { can be used as music accompaniment to Japin Carita are; Gasim, Takzim, Rawis, Melagu, Nyanyian, } \\
\text { and Tahtim. Japin music in Japin Carita theater is not only for the opening music, but also when } \\
\text { the actors enter and leave the stage, and for the closing music. Music illustrations depicting the } \\
\text { atmosphere of a place or the mood of an actor, whether sad, afraid, anxious, happy and so on must } \\
\text { alsofollow therhythm of Japin music. Japin Carita musical instruments consist of baboons, gongs, } \\
\text { violins, keprak, and gambus. The function of Japin music accompaniment includes entertainment } \\
\text { media, communication media, symbolic tribute, physical responses, continuity media, cultural } \\
\text { statistics, and atmosphere proponent of the Japin Carita play/ script. }\end{array}$ \\
\hline
\end{tabular}

Email : 1.bennymahendra@ulm.ac.id 


\section{INTRODUCTIONS}

The development of theater arts in South Kalimantan has been fast recently. This can be seen from the number of theater performances on television and in art buildings. Almost every month theater performances are performed by different theater communities at the Balairungsari building of the South Kalimantan Cultural Park. Almost all campuses and schools in South Kalimantan, especially in Banjarmasin, have theater communities.

The word theater comes from Greek, theatron which is derived from the word theamioi which means amazed to see. The word theater itself then represents three, namely; building, public (audience), tonil composition (tonel).

Theater art is a culture that exists in Indonesia which is always staged in an event, this theater art has different term from drama but in a broader sense, theater is a process of selecting text or script, interpretation, cultivation, presentation or performance, and understanding process or enjoyment of the public/ audience (readers, listeners, viewers, observers, critics, or researchers). Theater in a narrow sense is a drama of human life and life stories that are told on a stage, witnessed by many people and based on a written script. Theater is divided into two, namely modern theater and tradition/ traditional theater (Wiyanto, 2002).

Every aspect of traditional theater is adjusted to the conditions of traditional customs, processed according to the social conditions of the community, as well as the geographic structure of each area. Traditional theater has regional characteristics and depicts the culture of its environment.

The expressions of the artists in each region are not uniform. Differences in culture, social conditions and natural surroundings will form different arts. So it is not surprising, the diversity of cultural values in the archipelago gives rise to the art of the archipelago. Nusantara art is an expression of human ideas or feelings that contain the cultural values of the archipelago through behavior patterns that produce works that are aesthetically pleasing and meaningful. (Nasruddin, 2011:5).

One of the cultures that we must protect is traditional theater arts. Traditional theater is a complex art form, this is because it involves many other branches of art as supporting elements in their performances, such as fine arts, dance, and music. This aims to add to the aesthetic value as well as to strengthen the atmosphere and convey the message contained in the theater (Waluyo, 2000).
Japin Carita is a traditional theater art originating from South Kalimantan. Japin Carita is a very complex traditional art, in addition to acting performances by actors, Japin Carita involves dances and music in its show.

Traditional theater arts are often enjoyed by all people. This is because traditional theater is interesting, unique, and entertaining. Many people want to be involved in traditional theater, but not everyone can act well and freely and some people are hindered by feelings of shame and lack of confidence. On the other hand, the influence of modern theater has entered the archipelago so that traditional art is gradually being forgotten. The preservation of traditional art should be done immediately because it is part of the identity of local community, the younger generation is expected to be able to preserve and continue the natural culture of their own regions (Suroso, 2015).

The education system in Indonesia has started to strive to maintain the preservation of local arts in all regions in Indonesia, this can be seen in the regulation of the minister of education and culture number 37, about the basic competences of theater arts learning in 1oth grade for high school, which consists of basic competences of knowledge and basic competences of skills.

The government's efforts certainly require support from various aspects of education, one of which is learning resources. The availability of learning resources for traditional theater arts in South Kalimantan, based on the results of previous research, is stillverylimited.Cultural artsteachers in South Kalimantan find it difficult to find suitable sources of traditional theater arts, therefore researchers are interested in conducting research related to the form and function of music in Japin Carita in order to help the preservation and learning process of traditional theater arts, especially Japin Carita in South Kalimantan.

\section{METHODS}

The research method is an assessment of the steps in using the method (Sadarmayanti 2011 : 23). According to Sugiyono (2018:4) based on the objectives, research method can be classified into basic research, applied research, and developed research. Furthermore, based on thelevel of naturalness, research methods can be grouped into experimental, survey, and naturalistic methods.

Qualitative research methods are often called naturalistic research because it is conducted in a natural setting; This method is also known as the ethnographic method, initially this method was more widely used in the field of cultural anthropology; called a qualitative method 
because the data collected and analysis is more of a qualitative nature.

Based on the explanation above, the researcher uses qualitative research methods because this research will examine an object which is a product of a culture, this research will explore the history, form of performance, form of music, and the function of music from Japin Carita theater which will be described in descriptive data. This research is naturalistic in which the object of research develops by itself, the researcher does not manipulate the object and the presence of the researcher does not affect the object.

In this study the researchers conducted observations of a Japin Carita theater performance. As explained by Spradley (Sugiyono, 2018), the three components observed were Place, in this study place was not only a place where Japin Carita was performed but more about how the stage setting was in a show; Actors, in this study the actors are Japin Carita actors or players on stage, but in this study not only theater players but also music players or musicians cannot be separated from the researchers' observations; Activity, in this study the researcher observes all the activities of both actors and music players, according to their respective roles in Japin Carita. These observations were made to find data related to the form of performances, music accompaniment, and functions of music accompaniment in Japin Carita. The data was obtained by observing a Japin Carita theater performance.

\section{RESULTS AND DISCUSSION}

Japin Carita is a traditional theater art from South Kalimantan, which is derived from the Japin art, which is a dance originating from Arab, the origin of the word Japin in Arabic, Zafn, which means fast foot movements, and just like this definition, the Japin dance prioritizes foot movements.

Japin dance is an art that was brought to South Kalimantan by Islamic traders from Arabia, Persia and Gujarat together with their scholars and artists around the 13th century, in line with the development of Islam in archipelago. In 15th century the spread of Islam in Banjarmasin began to develop, as evidenced by the emergence of an Islamic kingdom in Banjarmasin.

The spread of Arabs in Banjarmasin can still be seen today, such as in Kampung Arab area, the Miai River and its surroundings. Arabs and Gujarati in the area often perform Japin dance performances, many local residents also witness the dance performances. This dance is then mixed with local culture in South Kalimantan to form a new art called BaJapin.

BaJapin is a Japin dance that includes the element of bakisah (storytelling) between performances. The addition of this storytelling element is inserted to entertain or it is suspected that the dancers are tired so they tell stories while taking a resting breath. BaJapin performances are often performed on the ground field or in the residents' yard with the concept of an arena stage. BaJapin art has developed and has sprung up in various regions in South Kalimantan, especially in the coastal areas of the river such as in Margasari in 1958 and in Kampung Binuang Dalam in 1975.

In 1980 s, the artist, cultural observer, and writer as well as the head of the South Kalimantan Cultural Park, Bakhtiar Sanderta tried to preserve this artistry, folk arts which contained dance, storytelling and performed in the field with the concept of the arena being rearranged in the form of drama, dance, music performances. which is structured and performed on the proscenium stage. Since then the art has been named Japin Carita.

The Japin Carita Theater was first performed around the 1980 s at the South Kalimantan Cultural Park, with title "Hayatun Nufus" which means breath of life.

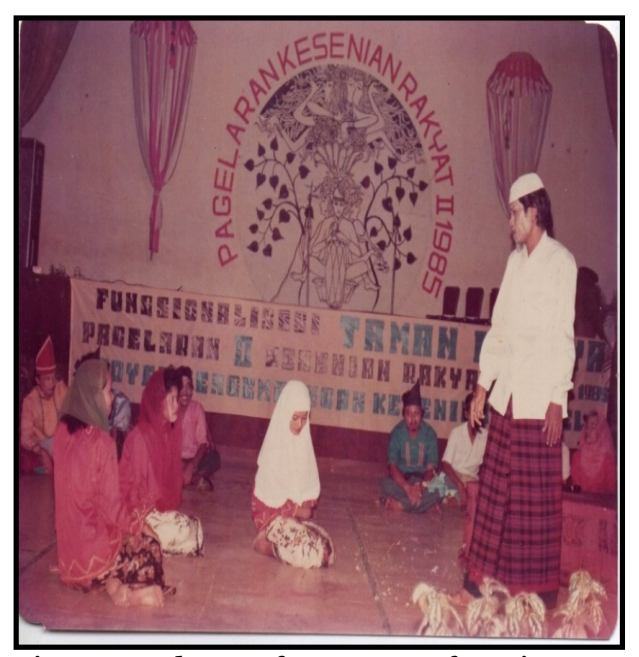

Figure 1: The performance of Japin

Carita Theater in Banjarmasin

The accompaniment of Japin Carita is Japin music, there is no specific standard for the song, the most important thing is the music must be in the rhythm of Japin. According to Banoe (2003 202), Japin's music is Malay music with Arabic influences. There are many types of Japin songs that can be used as accompaniment to Japin Carita theater such as, Japin Kuala, Japin Sisit, Japin Tuan Haji, Japin Rantauan, Japin Tirik Kuala, Japin Tirik Pindahan, Japin Kilir-Kiliran. Only because the first Japin Carita show used 
the song Japin rantauan and most of Japin Carita performances often used the song Japin rantauan, this song is often misinterpreted as the benchmark for Japin Carita, and thought they were obliged to use the song Japin rantauan. Whereas actually Japin Carita can use any Japin song as mentioned above, even Japin Carita's song can be made by the performer himself, the most important thing is that the music must be in the rhythm of Japin. Japin rantauan song notation, which is often used in Japin Carita performances, can be seen in the picture below:

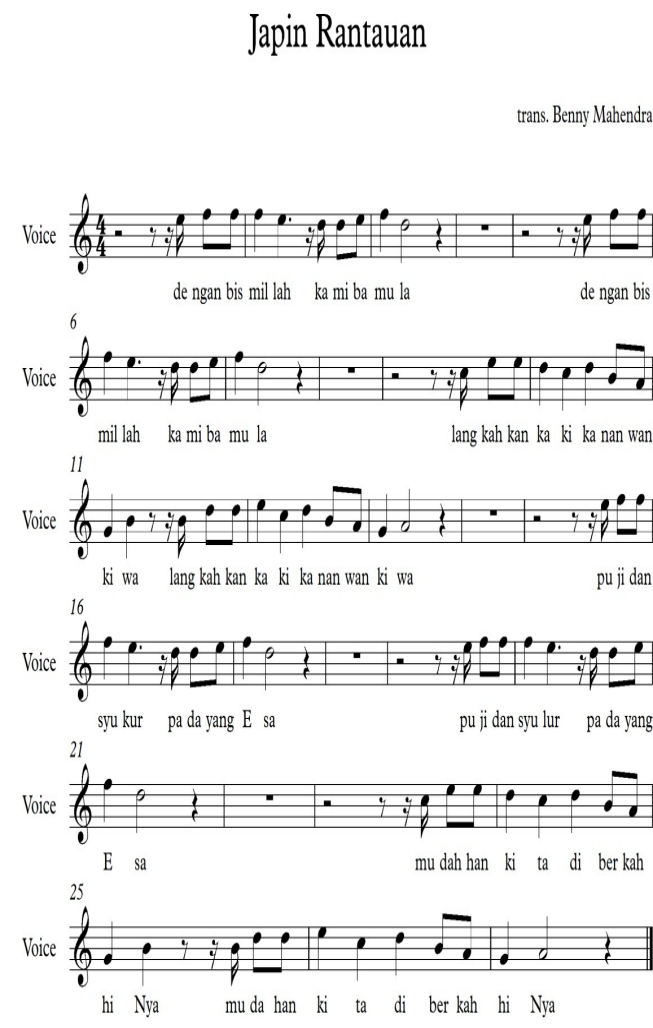

Figure 2: Japin Rantauan song partiture

As previously explained, there is no special song in Japin Carita, it doesn't always have to be a foreign Japin song. Songs can be self-created as long as they are Japin's music. The aim is that the songs created are in accordance with Japin's musical form. According to Maman (2012: $35^{-}$ 36) Japin's music structure consists of several parts consisting of Gasim, Takzim, Rawis, Melagu, Nyanyian, and Tahtim.

Based on the structure mentioned above, the Japin Carita music accompaniment can refer to those forms, which is as follows:

Gasim is a structure and form of play in Japin music which is played free of tempo (rall). In Japin Carita theater, this form of music is usually played at the beginning of the show's opening and as accompaniment to strengthen the atmosphere when Japin Carita plays. Such as strengthening the atmosphere of sadness, happiness, and so on.

Merawis is a structure and form of Keprak play that is usually played at the end of a song section as a sign of changing parts of the song or a sign that the singer starts singing.

Melagu is a structure and form of play in Japin music by playing several musical instruments consisting of rhythm, harmony and melody. This form of music is sort of like instrumental music with the rhythm of Japin music. In Japin Carita theater performances, this form of music is usually used as the turn of the round and when accompanying players enter the stage arena.

Nyanyian is a structure and form of play in Japin music by playing several musical instruments consisting of rhythm, harmony, melody and vocals. This form of music is usually used at the opening of the Japin Carita theater where actors enter the stage arena while singing.

Tahtim a term from Arabic, which means the last or the end. The meaning of Tahtim is the ending song. This tahtim (ending song) certainly applies to every Japin dance accompaniment, aftergoing through Melagu and Nyanyian several times. Usually the ending song has a special melody that is different from introduce melody and Melagu. In Japin Carita, Tahtim is usually used at the end of the performance or as a closing.

The use of Japin music in Japin Carita is not only for the opening, actors entering and leaving the stage, and the ending, but also music illustrations depicting the atmosphere of a place or the mood of an actor must be in rhythmwith Japin's music.

There are several kinds of musical instruments used in accompanying the Japin Carita theater, namely as follows;

1. Babun; membranophone percussion which has a tubular shape that has two side surfaces covered with skin.

2. Gong; idiophone percussion made of metal.

3. Violin; chordophone string instrument.

4. Keprak; short tube shaped membranophone percussion with two surface covered with skin.

5. Gambus; chordophone string instrument typically played by strumming or plucking the strings.

\section{The function of Japin Carita's music accompaniment}

Merriam (1964: 218) describes the function of music as follows:

1. Entertainment media

2. Communication media 
3. Symbolic tribute

4. Physical response

5. Form of harmony with community norms

6. Social institution and religiousrituals

7. Continuity media and culturalstatistic

Based on the musical functions mentioned above, there are also several musical functions in Japin Carita theater, which are as follows:

1. Entertainment media, the music accompaniment in Japin Carita is able to make the audience entertained.

2. Communication media, in Japin Carita music also functions as a medium of communication between actors, when actors enter the stage, start dancing, start singing and start having dialogue.

3. Symbolic tribute, meaning that music functions as a symbol of the cultural state of a society. The music accompaniment of Japin Carita can clearly explain the cultural condition of the community which is full of Islamic culture.

4. Physical response, in this case the music functions to accompany the actor while dancing.

5. Continuitymedia and cultural statistic, music accompaniment adds to the beauty of Japin Carita. In other words, the existence of music is able to support Japin Carita attracts public's interest and become sustainable.

6. Atmosphere proponent of the Japin Carita play/ script, music accompaniment in Japin Carita serves to support the atmosphere of the place setting and the mood of the actors.

\section{CONCLUSION}

The Japin Carita Theater was born in the 1980 's. The theater originated from the art of baJapin, baJapin is the art of Japin dance where storytelling acts are inserted in its presentation. This art comes from a mixture of the Japin Arabic dance, which was brought by Arab and Gujarati traders, with the culture of local community.

The accompaniment of Japin Carita is Japin music, there is no specific standard for the song.
The most important thing is the music must be in the rhythm of Japin, hence the musical accompaniment of Japin Carita theater must refer to the form and structure in Japin music. The forms and structures in Japin music consist of gasim. takzim, rawis, melagu, nyayian, and tahtim.

Apart from the shape and structure that refers to Japin music, the musical instruments used are also Japin musical instruments, such as babun, gong, biola, gambus, accordion, keprak.

The results of this study recommend further research on Japin Carita theater as a whole (performance forms, costumes and props). In addition, the results of this study can be used as a reference for further research and the manufacture of teaching materials for the local cultural arts of South Kalimantan in schools.

\section{REFERENCES}

Banoe, Pono. 2003. Kamus Musik. Yogyakarta: Kanisius.

Nasruddin T. 2011. Melestarikan Ragam Budaya Bangsa. Depok: Arya Duta.

Maman, Mukhils. 2012. Japin Banjar. Banjarmasin: Pustaka Banua.

Merriam, Allan P. 1964. The Anthropology of Music. Evanston: Northwestern University Press.

Sadarmayanti, Syarifudin Hidayat. (2011) Metodologi Penelitian. Bandung: Mandar Maju.

Sugiyono. 2018. Metode Penelitian Kuantitatif Kualitatif dan R\&D. Bandung: Alfabeta.

Suroso. 2015. Drama: Teori dan Praktik Pementasan. Yogjakarta: Elmatera

Wiyanto, Asul. 2002. Terampil Bermain Drama. Jakarta: Grasindo

Waluyo, Herman J. 2000. Teori dan Apresiasi Drama. Jakarta: Erlangga 